\title{
Inclusion and Cultural Preservation for the Ifugao People
}

\author{
Ellisiah U. Jocson \\ Managing Director, OneLife Foundation Inc. (OLFI), M.A.Ed Candidate, \\ University of the Philippines, Diliman
}

\begin{abstract}
This study seeks to offer insight into the paradox between two ideologies that are currently being promoted in Philippine society and identify the relationship of both towards the indigenous community of the Ifugao in the country. Inclusion is a growing trend in many areas, such as education, business, and development. However, there is ambiguity in terms of educating and promoting inclusion for indigenous groups, particularly in the Philippines. Mandates to promote cultural preservation also present limits to the ability of indigenous people to partake in the cultures of mainstream society. The Ifugao, together with other indigenous tribes in the Philippines, are at a state of disadvantage due to the discrepancies between the rights that they receive relative to the more urbanized areas of the country. The desire to preserve the Ifugao culture and to become inclusive in delivering equal rights and services create divided vantages that seem to present a rift and dilemma deciding which ideology to promulgate. Apart from these imbalances, the stance of the Ifugao regarding this matter is unclear, particularly if they observe and follow a central principle. Given that the notion of inclusion is to accommodate everyone regardless of "race, gender, disability, ethnicity, social class, and religion," it is highly imperative to provide clarity to this issue and identify what actions to take. This study aims to understand how the Ifugao people are perceived, implemented, and integrated. The study will also look for manifestations in three culture groups of the Ifugao, namely the Lamut, Lagawe, and Banaue. It is important for the indigenous people of the Philippines to clearly understand inclusion in order to be guided in accepting its mandates without jeopardizing their cultural identity. Likewise, this study would also be beneficial in the fields of cultural and anthropological studies, as it raises the awareness of the current state of the Ifugao by zeroing in on the paradox between the two ideologies. The study uses a qualitative-case study design, obtaining data through a review of documents and policies, interviews, and observations in order to identify the current status of both ideologies in terms of implementation, integration, and acceptance for the Ifugao people in the Philippines.
\end{abstract}

Keywords: Indigenous People, Inclusion, Cultural Preservation, Cultural Diversity 


\section{INTRODUCTION}

\section{Indigenous People of the Philippines}

Indigenous people make up 5\% of the world's population and control approximately 1 quarter or 14.7 million square miles of land in 87 regions. ${ }^{1}$ The term "indigenous peoples" (IPs) is legally defined in the Philippine Republic Act 8371, otherwise known as the Indigenous Peoples Rights Act (IPRA), as:

"A group of people or homogeneous societies identified by selfascription and ascription by others, who have continuously lived as organized community on communally bounded and defined territory, and who have, under claims of ownership since time immemorial, occupied, possessed and utilized such territories, sharing common bonds of language, customs, traditions and other distinctive cultural traits, or who have, through resistance to political, social and cultural inroads of colonization, non-indigenous religions and cultures, become historically differentiated from the majority of Filipinos."

The Philippines is the only country in Asia to officially and legally use the term, "indigenous people." As legislation, the Republic Act 8371, or the "Indigenous Peoples Rights Act," mandates the protection, promotion, and fulfillment of the rights of Indigenous Peoples (IPs). This acceptance of IPs recognizes four distributions of rights: the right to ancestral lands and domains; the right to self-governance and empowerment; the right to social justice and human rights; and the right to self-determination. ${ }^{3} ;{ }^{4}$ In the Philippines there are a wide variety of cultures, amounting to 110 ethno-linguistic groups composed of approximately 14-17 million indigenous people (IPs) spread across the country such as in Northern Luzon (33\%), Mindanao (61\%) and the remaining are

1 Daley, Jason "Indigenous Peoples Manage One Quarter of the Globe, which is Good News for Conservation" (2018). online: <https://www.smithsonianmag.com/smart-news/indigenous-peoplemanage-one-quarter-globe-which-is-good-news-conservation-180969689/>

2 Republic Act No. 8371 "Indigenous Peoples Rights Act" (29 October 1997), online: 〈https://www.lawphil.net/statutes/repacts/ra1997/ra_8371_1997.html>

3 Asian Development Bank, "Indigenous Peoples/Ethnic Minorities and Poverty Reduction" (2002) Pasig City, Philippines at 4

4 United Nations Development Program "Indigenous Peoples of the Philippines" (2013) Makati City $1226 \quad$ Philippines. online:〈http://www.ph.undp.org/content/philippines/en/home/ibrary/democratic_governance/Fa stFacts-IPs.html $>$ at 1 
interspersed in the Visayas region, therefore such legislation as the Republic Act 9371 earmarks social and protection rights for IPs as extremely necessary. ${ }^{5}$

IP groups in the Philippines can be classified under eight (8) major groups that are scattered among the country's three main islands, Luzon, Visayas, and Mindanao. These eight (8) groups are namely: the Negrito of Luzon, the Igorot, the Mangyan, the Ati, the Lumad, the Bajau, the tribes of Palawan, and the tribes of Panay. Figure 1 below illustrates the geographic distribution of the groups throughout the country and Figure 2 shows the population of IP groups in each region of the Philippines.

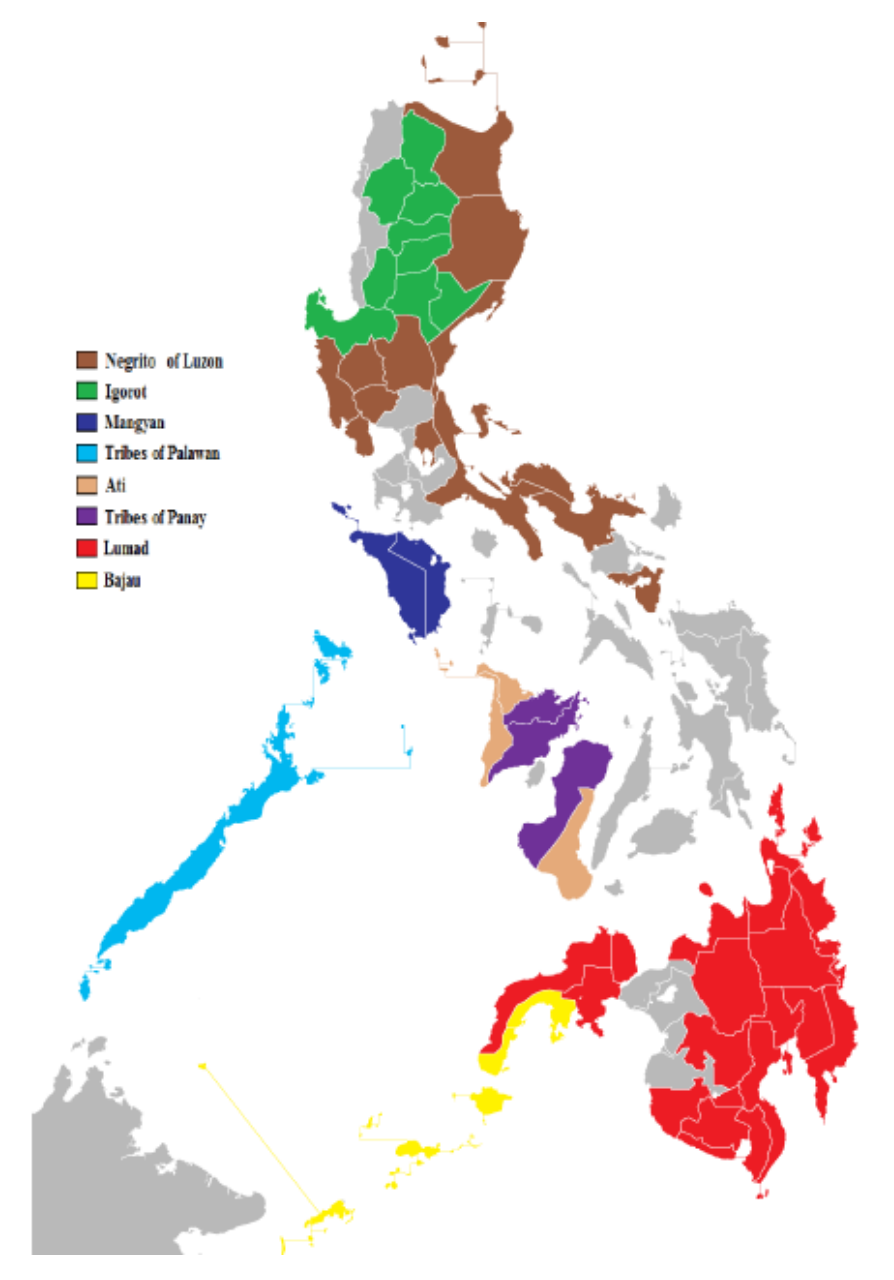

Figure 1: Distribution of Major IP groups in the Philippines. ${ }^{6}$

5 Alicias, Maria Dolores "The Socially Excluded Groups in the Philippines: A Context Analysis for the Voice Program" (2017) Hivos, Oxfam Novib, Ministry of the Foreign Affairs of the Netherlands. at 102-103 


\begin{tabular}{|l|l|}
\hline Cordillera Autonomous Region (CAR) & $1,252,962$ \\
\hline Region I & $1,039,447$ \\
\hline Region II & $1,014,955$ \\
\hline Region III & 230,270 \\
\hline Region IV & 714,527 \\
\hline Region V & 185,488 \\
\hline Region VI and VII & 175,109 \\
\hline Region IX & 993,232 \\
\hline Region X & $1,509,436$ \\
\hline Region XI & $1,882,622$ \\
\hline Region XII & $1,447,972$ \\
\hline Region XIII & 874,456 \\
\hline Total & $11,320,476$ \\
\hline
\end{tabular}

Figure 2: Composition of IPs in the Philippines per Region. ${ }^{7}$

IPs inhabiting Mindanao consist of the Moros and the Lumads, with the Lumads composing of the "Bagobo of Davao del Sur, South and North Cotabato, and Sultan Kudarat; Mansaka of Davao del Norte; Mandaya of Davao Oriental; Subanen of the Zamboanga Peninsula; B'laan of Davao del Sur, South Cotabato, North Cotabato, Maguindanao, and Sultan Kudarat; T'boli of South Cotabato; and Tiruray of North Cotabato, Maguindanao and Sultan Kudarat." IPs in the Cordillera region are collectively referred to as the Igorot, with groups such as the Ibaloy, Kankanaey, Bontoc, Ifugao, Kalinga, Isneg, Tinggian, and Kalanguya residing in the provinces of Ifugao, Kalinga, Apayao, Benguet, Mountain Province, and Baguio City. ${ }^{9}$ However, identifying, recognizing, and classifying people and minorities as indigenous is unclear due to a lack in data. With the

6 Foundation for the Philippine Environment "Where are Indigenous Peoples Distributed in the Philippines??"(n.d). online: 〈https://fpe.ph/research/print_mpdf/26>

7 National Commission on Indigenous Peoples "Indigenous Peoples of the Philippines" (n.d) online: 〈http://www.ncipro67.com.ph/indigenous-peoples-of-the-philippines/>

8 Asian Development Bank, "Indigenous Peoples/Ethnic Minorities and Poverty Reduction" (2002) Pasig City, Philippines at 4

9 Alicias, Maria Dolores "The Socially Excluded Groups in the Philippines: A Context Analysis for the Voice Program" (2017) Hivos, Oxfam Novib, Ministry of the Foreign Affairs of the Netherlands. at 103 
numbers by government agencies and regional offices presenting disaggregated statistics, the actual population of IPs in the Philippines has yet to be clarified. ${ }^{10}$

Indigenous people in the Philippines have their own social, political, and cultural systems which they have continuously maintained before, during, and after the country became colonized up until this modern era. ${ }^{11}$ The history of IPs and their experiences are riddled with discrimination, marginalization, and victimization. The implementation of the Indigenous Peoples Rights Act (IPRA) seeks to address these experiences and help alleviate the status of IPs through four categories of rights: the right to self-governance and empowerment, the right to self-determination, the right to social justice and human rights, and the right to ancestral lands and domains. ${ }^{12}$ The specific components that determine an IPs identity such as territoriality, communal boundedness, and homogeneity are also stated in the IPRA, ${ }^{13}$ but the components are contested due to its generalizing effect in contrast to the changes that is occurring to IP groups. ${ }^{14}$

This legislation seems to be failing as IPs still belong to the most disadvantaged and poorest groups which face discrimination, exclusion and social inequities in health, education, and human rights. ${ }^{15}$ Actions from both the local and national government and private organizations to continuously support and assist IPs to achieve a streamlined social and environmental protection through sustainable development plans, land conservation programs and capacity building programs. IPs in the Philippines are also facing marginalization from economic and political processes, displacement and the destruction of the traditional way of life, practices, culture, and identity, so much so that some groups resorted to violence and took up arms, resulting in conflicts such as the 40year old armed conflict in Mindanao. ${ }^{16}$

${ }^{10}$ Tebtebba "Situation of Indigenous Peoples in the Philippines: Submission to the 59th Session of CESCR" (2016) online:< http://tebtebba.org/index.php/content/383-situation-of-indigenouspeoples-in-thephilippines-submission-to-the-59th-session-of-cescr>

11 Alicias, Maria Dolores "The Socially Excluded Groups in the Philippines: A Context Analysis for the Voice Program" (2017) Hivos, Oxfam Novib, Ministry of the Foreign Affairs of the Netherlands. at 102

12 Alicias, Maria Dolores "The Socially Excluded Groups in the Philippines: A Context Analysis for the Voice Program" (2017) Hivos, Oxfam Novib, Ministry of the Foreign Affairs of the Netherlands. at 102

13 Republic Act No. 8371, "Indigenous Peoples Rights Act" (29 October 1997) 〈https://www.lawphil.net/statutes/repacts/ra1997/ra_8371_1997.html>

14 Alicias, Maria Dolores "The Socially Excluded Groups in the Philippines: A Context Analysis for the Voice Program" (2017) Hivos, Oxfam Novib, Ministry of the Foreign Affairs of the Netherlands. at 104

15 Ibid at 110

16 United Nations Development Program "Indigenous Peoples of the Philippines" (2013) Makati City $1226 \quad$ Philippines. online:〈http://www.ph.undp.org/content/philippines/en/home/ibrary/democratic_governance/Fa stFacts-IPs.html > at 1 


\section{Cultural Preservation}

Culture has various definitions, such as "...something that is shared and/or learned by a group of people, but the content of the culture varies in different definitions." ${ }^{17}$ Culture contains a set of traits such as behavior, knowledge, ideas, beliefs, norms, and facts. $\left.{ }^{18}\right|^{19}$ Another definition for culture is a "community or population sufficiently large enough to be self-sustaining, able to produce new generations of members without relying on outside people, with a collective thought, experiences, and patterns of behaviour and its concepts, values, and assumptions about life that guide behaviour and how those evolve with contact with other cultures" 20 and "with each society having its own shape, purpose and meaning expressed through different forms." ${ }^{21}$. Hofstede classified the elements of culture into four categories: symbols, rituals, values, and heroes ${ }^{22}$, which can be found in espoused values, basic assumptions, and observable artifacts. ${ }^{23}$

The need to preserve one's culture is essential, particularly due to the role it plays in preserving the identity of a specific group of people. Having a strong sense of self identity through culture creates a larger possibility for peaceful interactions with other cultures while also observing respect for the differences between groups. Maintaining cultural differences is in fact not new in international law. ${ }^{24}$ Cultural preservation, therefore, is vital for peaceful cooperation of civilizations. ${ }^{25}$ Culture, according to the Convention on the Rights of the Child (CRC), is a responsibility that all states and countries have to carry. Accordingly,

17 Birukou, Aliaksandr, Blanzieri,Enrico, Giorgini, Paolo, Giunchiglia, Fausto " $A$ Formal Definition of Culture” (n.d). DISI, University of Trento, via Sommarive 14, Povo(TN), Italy 38100 online:

18 <https://pdfs.semanticscholar.org/6b6e/052a0c179581ef48b0aa6728b2dea4432c53.pdf > at 3

Ibid at 3

19 Axelrod, Robert "The dissemination of culture: A model with local convergence and global polarization" (1997) The Journal of Conflict Resolution 41(2) 203-226. online: <http://users.softlab.ntua.gr/ brensham/CourseSoc/Axelrod1997.pdf > at 208

20 "Defining Culture and Identities"(n.d). online: 〈http://www.sagepub.com/sites/default/files/upm-binaries/45974_Chapter_1.pdf> at 6

21 Williams, Raymond. "Culture is Ordinary" (1958). Convictions. online: <http://www.cs.cmu.edu/ cfrieze/courses/Culture_definitions.pdf $>$

22 Birukou, Aliaksandr, Blanzieri,Enrico, Giorgini, Paolo, Giunchiglia, Fausto " $A$ Formal Definition of Culture” (n.d). DISI, University of Trento, via Sommarive 14, Povo(TN), Italy 38100 online: <https://pdfs.semanticscholar.org/6b6e/052a0c179581ef48b0aa6728b2dea4432c53.pdf > at 3

23 Tharp, Bruce M. "Defining "Culture" and "Organizational Culture": From Anthropology to the Office" (2009). online: <http://www.thercfgroup.com/files/resources/Defining-Culture-andOrganizationa-Culture_5.pdf>

24 Kugelmann, Dieter. "The Protection of Minorities and Indigenous Peoples Respecting Cultural Diversity” (2007) Max Planck Yearbook of United Nations Law, Volume 11, 2007. P233-263. Koninklijke. Netherlands at 239

25 Thomas-Hoffman, Elizabeth A. "Cultural Preservation and Protection" (n.d.) online: <http://www.mesacc.edu/ -bricl07041/un/hs/culture.pdf $>$ at 1 
Articles 8, 20, and 30 of the CRC states that cultural, ethnic, religious, and linguistic components are part of the rights of children. The obligation to preserve a child's cultural identity in recognition of its contribution to his or her development must be carried out by the government and other legal bodies, ${ }^{26}$ with the obligation viewed as a form of respecting the traditions that these cultures value. ${ }^{27}$ The United Nations Education Scientific and Cultural Organization (UNESCO) is the UN's main arm in protecting and preserving culture, which includes the protection of cultural sites and artifacts, human rights, intellectual property rights for culture-specific art and languages, development, and tolerance. Several policies and mandates have been enacted to strengthen this prerogative, including numerous declarations, policies, and mandates all in the pursuit of the promotion, preservation, and protection of the cultural and developmental rights of all people. Examples of these policies are the Declaration of the Principles of International Cultural Co-operation (1966), the Convention Concerning the Protection of the World Cultural and Natural Heritage (1972), the International Covenant on Economic, Social and Cultural Rights (1976), the UNESCO Declaration on Race and Racial Prejudice (1978), the Declaration on the Elimination of All Forms of Intolerance Based on Religion or Belief (1981), and the Declaration on the Rights of Persons Belonging to National or Ethnic, Religious and Linguistic Minorities (1992). ${ }^{28}$ The most recent and specific mandate is the Declaration of the Rights of Indigenous People (UNDRIP), which contains 46 articles that affirm, recognize, and emphasize the rights of indigenous people. $^{29}$

However, despite these mandates and the acknowledgment of the role that culture plays in development and especially in the development of children, translating policies into appropriate systems of delivery and other components continue to be a challenge for many countries. ${ }^{30}$ Threats to cultural preservation also persist, with forces such as modernization, socio-economic development, and

26 United Nations "Conventions on the Rights of the Child" (1989) UNICEF UK 30a Great Sutton Street London. $\quad$ online: $\quad$ https://downloads.unicef.org.uk/wpcontent/uploads/2010/05/UNCRC_united_nations_convention_on_the_rights_of_the_child.pdf? ga=2.216050582.1629100116.1531192672-1628603561.1531192672>

27 United States Department of State "2005-2006 Annual Report on the U.S. Ambassadors Fund for Cultural Preservation" Bureau of Educational and Cultural Affairs, United States Department of State (2006). online: <https://eca.state.gov/files/bureau/2005-6afcpannual.pdf> at 5

28 Thomas-Hoffman, Elizabeth A. "Cultural Preservation and Protection" (n.d.) online: <http://www.mesacc.edu/ bricl07041/un/hs/culture.pdf> at 2

29 United Nations "Declaration of the Rights of Indigenous Peoples" (2008). online: <http://www.un.org/esa/socdev/unpfii/documents/DRIPS_en.pdf>

30 United Nations Educational, Scientific and Cultural Organization (UNESCO) "Thematic Paper on Education and Indigenous Peoples: Priorities for Inclusive Education” (2014) Bangkok, Thailand. online: <http://www.un.org/en/ga/president/68/pdf/wcip/IASG\%20Thematic\%20Paper_\%20Education\%20$\% 20 \mathrm{rev1.pdf>}$ 
migration influencing indigenous people to absorb these ideologies and systems. Ethnic identity is in peril of being lost primarily due to rapid urbanization brought upon by the call to synchronize all societies into the strife for a global community. This rapid urbanization forces minority groups to undergo autopoiesis, or the process of self-reorganization of one's own culture. The aim for social synchronicity, therefore, might results in de-culturalization of minority groups such as IPs. 31

\section{Inclusion}

Human development is an important component of human existence. It entails freedom to fully realize the potential of human life. Human development has greatly enriched ways of life; great progress has been made in the field of human development, such as longer life expectancies, alleviation from poverty, greater access to basic social services, and, generally, the removal of human deprivations. Yet, not everyone has been reached by this progress. ${ }^{32}$ Efforts are being made to reach the unreachable in order to attain universality. But, the question remains, how can progress development offer a consolidated approach towards a highly diverse world?

With the existing differences between people and social groups, it is often wondered what is the most effective approach to take regarding the reception of components that are deemed to be humanely just. Social groups that share commonalities are often categorized into majorities and minorities, but this categorization remains unclear due to the lack of a cohesive definition for the term "minority." Straying away from what a large group practices and implements, such as having a different culture, can lead to discrimination and suppression because that specific minority, through the eyes of a majority, is seen as different or deviant. Social definitions of deviancy apply to persons or individuals that are seen as significantly different, and the difference is valued negatively. ${ }^{34}$ It must be pointed out that it is society itself that determines who is deviant, with various standards being used as the determinant of who is different and who is not. Its implications to how one perceives a specific culture is enormous, and with the rich

31 Goda, Toh. "Urbanization and Formation of Ethnicity in Southeast Asia" (2009) New Day Publishers. Quezon City, Philippines

32 United Nations Development Program "Human Development Report 2016: Human Development for Everyone" (2016) 1 UN Plaza, New York, NY 10017 USA at iii

33 Kugelmann, Dieter. "The Protection of Minorities and Indigenous Peoples Respecting Cultural Diversity” (2007) Max Planck Yearbook of United Nations Law, Volume 11, 2007. P233-263. Koninklijke. Netherlands at 237

34 Wolfsenberger, Wolf P., Nirjie, Bengt, Olshansky, Simon, Perske, Robert, Roos, Philip. “The Principle of Normalization in Human Services.Books: Wofsenberger Collection 1" (1972) National Institute on Mental Retardation. online: <http://digitalcommons.unmc.edu/wolf_books/1> at 13 
diversity of groups and cultures, many are bound to become deviant through the multitude of lenses seeking a standard way of life.

Normalization, or the "utilization of means which are as culturally normative as possible in order to maintain and/or establish personal behavior and characteristics, which are as culturally normative as possible" ${ }^{35}$ is an effort to uphold the rights of an individual who is viewed to be deviant. Initially focused on persons with disabilities, this principle has progressed and evolved into the principle of inclusion. This principle stems from the Salamanca Statement, a cohesive stand of 92 governments in order to deliver equal rights for people with disabilities. Inclusion seeks to accommodate all children regardless of physical, intellectual, social, emotional, linguistic, or other conditions, as well as children belonging to ethnic or cultural minorities and children from marginalized or disadvantaged groups. ${ }^{36}$ Inclusion is a humanistic approach which emphasizes the increased participation in education, the value of all students, and acknowledges their right to education. ${ }^{37}$

Since then, inclusion has been adapted by other fields and sectors apart from education. Inclusive Development became an area of focus for many sectors, such as businesses or social work. With the UNDRIP acting as a legislative support for these developments, inclusive development of indigenous peoples is now supported by numerous organizations. For instance, the International Labour Organization (ILO) implemented a development program entitled Interregional Programme to Support Self-Reliance of Indigenous and Tribal Communities through Cooperatives and Other Self-help Organizations or INDISCO. ${ }^{38}$ This development program is run by a community-driven, participatory approach aimed to preserve and promote indigenous culture, opportunities for income and employment, gender equality, and protection and rehabilitation of the environment and natural resources. The project involved two indigenous communities in the Cordillera, four in Mindanao, two in Occidental Mindoro and one in Zambales. The United Nations Development Programme (UNDP) also implemented programs such as the Global Environment Facility-Small Grants Programme (GEF-SGP) that seek to promote biodiversity conservation, protect international waters from environmental impacts, and reduce the emission of

35 Wolfsenberger, Wolf P., Nirjie, Bengt, Olshansky, Simon, Perske, Robert, Roos, Philip. “The Principle of Normalization in Human Services.Books: Wofsenberger Collection I" (1972) National Institute on Mental Retardation. online: <http://digitalcommons.unmc.edu/wolf books/1> at 28

36 United Nations Educational, Scientific and Cultural Organization (UNESCO) "The Salamanca Statement and Framework for Action on Special Needs Education” (1994) Paris, France. online: 〈http://unesdoc.unesco.org/images/0009/000984/098427eo.pdf> at 6

37 Booth, Tony and Ainscow, Mel "Index to Inclusion: Developing Learning and Participation in Schools" (2002) Center for Studies in Inclusive Education. at 3

38 International Labour Organization "Interregional Programme to Support Self-Reliance of Indigenous and Tribal Communities through Cooperatives and Other Self-help Organizations" (2007). online: 〈http://www.ilo.org/manila/projects/WCMS_125280/1ang-en/index.htm> 
greenhouse gases. These have been translated into projects that involve NGOs and IPs. The Philippine-Australia Community Assistance Program (PACAP) seeks to raise the living standards of poor and marginalized Filipinos with projects in agricultural development and environmental management which involve indigenous peoples. The World Bank has also included IPs in its operations, such as with bank projects that allow IPs to be implemented through their Operational Directive 4.20. The World Bank initiatives account for a total of 24 projects in the Philippines. Local organizations also conduct projects where IPs live. These projects deal in education, agrarian reform, water, finance, and other areas of development. $^{39}$

The acceptance and implementation of these mandates, legislations, and projects are beneficial for IPs, particularly because it aims to equalize their status in rights-reception by promoting what is currently being advocated in the mainstream society, thereby including IPs and emphasizing universality. However, this approach raises the question, "if a specific culture seems lacking in one of the components proposed by the convention, or if one or more of the rights are unobserved by a group, yet it is the norm of their culture, should there be intervention?" The concept of cultural relativism, the idea that human values vary with different cultural perspectives, should be regarded in the pursuit to promote universal human rights. ${ }^{40}$ This is especially true for indigenous people. UNDRIP's articles use terminologies that emphasizes the importance of the decision of IP groups in terms of partaking in the tenets of mainstream society. The use of the process of free, prior and informed consent (FPIC) aims to address this concern. However, despite garnering consent, IPs are still subjected to making decisions that might result in difficulties in the long term, especially when a general provision or policy is espoused.

\section{THE PEOPLE OF IFUGAO}

The word "Ifugao" stems from "pugaw," meaning "earthworld," which is believed to be the habitat of humans and various groups of earth spirits in Ifugao mythology. The Ifugao province is established under the Philippine Republic Act 4695 of 1966, dividing the old Mountain Province into four provinces: Benguet, Ifugao, Kalinga-Apayao, and Mt. Province or Bontoc. ${ }^{41}$ Ifugao is generally a mountainous area, located in the southeastern section of the Cordillera Administrative Region (CAR) in Northern Luzon, the largest of the islands in the

39 Asian Development Bank, "Indigenous Peoples/Ethnic Minorities and Poverty Reduction" (2002) Pasig City, Philippines at 45

40 Thomas-Hoffman, Elizabeth A. "Cultural Preservation and Protection" (n.d.) online: $<$ http://www.mesacc.edu/ -bricl07041/un/hs/culture.pdf $>$ at 4

41 Dulawan, Manuel. "The Ifugao" (2006). National Commission on Culture and the Arts, Philippines. at 1 
Philippines. The province spans an area of 3,500 square kilometres, which currently holds a total population of 202,802 people. ${ }^{42}$

The Ifugao have established their community, which is composed of 12-30 houses in the Cordillera region ${ }^{43}$ sharing the area with other IPs such as the Tingguian, Isneg, Bontok, Kankana-ey, Ibaloi, Ibanag, and Kalinga. ${ }^{44}$ Together with the Bontok, the Ifugao are regarded as cultivators of the Proto-Malayan rice field terrace ${ }^{45}$, and they rely on agriculture as their main source of living. Based on their mythical stories, the Ifuago ancestors came from the descendants of the Kabunyan deities, Wigan and Bugun, who migrated to Pugaw, the place where only earth spirits and deer lived. ${ }^{46}$ Their first settlement was set at a place near the bank of the Ibalao River in Kiangan on the side opposite of the present town, Lagawe. When a great flood submerged the whole Pugao, only two of their children survived, making them agree to be husband and wife and populate the Pugao again. Aside from the mythical story, there are other theories of the origin of the Ifugao including those by Beyer, Keesing, and Barton. Cited by oral literary and linguistic proofs, Dulawan is convinced that, centuries ago, people from the Ilocos moved from their region to the Cordillera mountain region, while people from the Tadian-Bauko area in Western Mt. Province also did the same. Through the years, descendants of these migrating people populated the whole Ifugao. The population of Ifugao was affected over time by epidemics of dysentery and malaria, as well as the war between the Japanese and the Fil-American forces. The Ifugao are composed of two distinct ethnic subgroups, the Ayangan and the Tuwali. They are divided based on the difference in dialects, the Ayangan dialect and the Tuwali medium, as well as through their customs and costumes. Tuwali have their own chants called alim and hudhud which the Ayangan do not have. Their costumes differ in design and color schemes. At present, the majority of the Ifugao people belong to the Ayangan. In the search for better economic opportunities, families from the Ifugao migrated to the lowlands while migrants from Ilocos and Kalinga inhabited the Ifugao region which affected the population

\footnotetext{
42 Philippine Statistics Authority "Ifugao Quickstat" (2018) online: <https://psa.gov.ph/content/ifugao-quickstat-june-2018>

43 Ethnic Groups of the Philippines "Ifugao Amganad" (2011). online: <http://www.ethnicgroupsphilippines.com/people/ethnic-groups-in-the-philippines/ifugaoamganad/>

44 Goda, Toh “Cordillera: Diversity in Culture Change” (2001). New Day Publishers. Quezon City at 1

45 Ibid. at 1

46 Dulawan, Manuel. "The Ifugao" (2006). National Commission on Culture and the Arts, Philippines. at 2
} 
of the area, ${ }^{47}$ resulting to intermarriage between the Ifugaos and Ilocanos, the native dwellers of the Ilocos region of the Philippines. ${ }^{48}$

Looking at the Ifugao's culture, traditions, past behavior, and lives as a sociocultural group, traditions such as myths, chants, genealogies, and other forms of folklore are passed on orally due to absence of a writing system. ${ }^{49}$ Early writings about the Ifugao were mostly produced by Spaniards, whose main intentions were to build their military bases in the area and put the Ifugao under their rule. However, the Ifugao rejected these, leading to a revolt. This revolt led the Ifugao to be known as "headhunters." 50 Efforts were made to pacify the Ifugao throughout the years. ${ }^{51}$

Economically, the Ifugao deal in agriculture, particularly in rice, fruits (such as bananas and pomelos), and coffee products from Lagawe, Lamut, Kiangan, and Asipulo. Progress in the area has boosted the influx of tourists and prompted the establishment of business institutions being put in demand, such as lodging houses, restaurants and eateries. ${ }^{52}$ These establishments and systems greatly affect the Ifugao people. The developments that are progressively built put pressures on the Ifugao, and the documented history of the pressures they face from modern "civilization" is positioned negatively. Standardized school books and the influences of foreign indoctrination are impeding the Ifugao from upholding their rich heritage. The call for a "uniform pedagogy" unwittingly forces the Ifugao to adopt the ways of the dominant Filipino culture. To ameliorate the forced transformations and neglects that the Ifugao have experienced, it is necessary to preserve the rituals, histories, and culture of these people along with other indigenous groups. ${ }^{53}$ Currently, the Ifugao have already faced the threats of modernization and globalization. The cultural brainwashing and its effects on the Ifugao youth have been "traumatic, sad and painful," with most of the Ifugao becoming strangers to their ancestral traditions and values due to their adaptation and adoption of influences from standardized schooling and other religions. These influences condition them into believing that anything that originates from the

47 Dulawan, Manuel. "The Ifugao" (2006). National Commission on Culture and the Arts, Philippines. at 1-4

48 Interviewed members of the Ayangan and Tuwali tribes from Banaue, Lamut and Lagawe areas.

49 Ibid, at 5

50 Ibid, at 9

Ibid, at 12

Ibid, at 22

53 Amores, Analyn, Enkiwe-Abayao, Leah, Martin, Marlon, Tolentino, Delfin "Ifugao: People of the Earth"(2017). ArtPostAsia \& Aboitiz Group of Companies. Philippines 
Ifugao culture is "not good or inferior." Such loss of appreciation posits a highly dangerous position for the existence of the culture, its traditions and practices. ${ }^{55}$

\section{CULTURAL PRESERVATION IN IFUGAO}

The Ifugao culture, being rich and colorful in terms of their tangible and intangible heritage, is safeguarded, conserved, and protected through the policies under the IPRA and sustained through local policies and ordinances. These policies and ordinances include the Provincial Ordinance No. 2013-22, "An Ordinance Enacting the Ifugao Cultural Code." The main purpose of this ordinance is to preserve and promote cultural heritage through establishing and strengthening institutions such as museums, preserving relics, buildings and historical landmarks. Another method of preserving cultural heritage is by promoting the cultural resources, as well as protecting the Ifugao's ownership and custody of each of their community's culture. The efforts of this Provincial Ordinance involve their provincial government in creating programs that enable the cultural transmission and education to the younger generations through the restoration of their own languages and orthographies, which allows them to take control over the cultural research and cultural heritage. There are also other provisions in the cultural code which include the creation of a policy making body, the Ifugao Provincial Council for Cultural Heritage, to ensure the implementation of the programs, and the establishment of the Ifugao Registry of Cultural Properties where all the cultural properties will be listed. ${ }^{56}$

The Provincial Ordinance No. 2013-22 mandates the incorporation of the Ifugao heritage studies in formal and non- formal education systems in the province is given significance to ensure the transmission of the traditions. ${ }^{57}$ In the primary school years, through the Mother Tongue-Based Multi-Lingual Education (MTB-MLE), ${ }^{58}$ the Ifugao language is used, together with the Ilocano language, in teaching their basic subjects. Traditions such as cultural dances, music, and rites are also discussed in the Social Studies education. They also have a cultural fair in

54 Dulawan, Manuel. "The Ifugao" (2006). National Commission on Culture and the Arts, Philippines.

55 Dulawan, Manuel. "Ifugao: A sociocultural and Political History" (n.d.) National Commision for Culture and the Arts. Manila, Philippines

56 Ifugao Cultural Heritage Office (ICHO) "2014 State of Conservation Report: Rice Terraces of the Philippine Cordilleras. (2014) Ifugao Cultural Heritage Office \& Philippine National Commission for UNESCO at 8-9

57

Ibid, at 9

58 Metila, Romylyn., Pradilla, Lea Angela., \& Williams, Alan. "Investigating best practice in Mother Tongue-Based Multilingual Education (MTB-MLE) in the Philippines, Phase 2 progress report: Patterns of challenges and strategies in the implementation of mother tongue as medium of instruction in the early years: A nationwide study" (2016). Australian Department of Foreign Affairs and Trade and Philippine Department of Education. Melbourne and Manila: Assessment, Curriculum and Technology Research Centre (ACTRC) at 9 
school in which they wear the costume of the tribe to which they belong. ${ }^{59}$ Indigenous games, such as "bultung," where children also wear the traditional costume "bahag," "60 are also played in their Physical Education classes. ${ }^{61}$ During special occasions, children and youth also dance the traditional dance, "cañao," which they dance to music played using "gadang" or gongs. 62

Other efforts, such as conducting festivals called Gotad Ad Ifugao, are done annually in order to showcase the rich culture of the Ifugao. "Munpaot" (woodcarving), "bultung" (wrestling). "tayo" (native dance), "hudhud" (chanting), and other indigenous practices are presented during the weeklong festival which pushes for inclusive growth anchored in their culture and tourism. ${ }^{63}$ One of their valued properties that promotes tourism is the Rice Terraces. Heralded as one of the Eight Wonders of the World, declared a National Treasure in the Philippine Presidential Decrees (PD) 260 of 1973 and PD 1505 of 1978, and protected under the Republic Act No 10066 of 2010. The Rice Terraces are protected and managed by the Ifugao community through the Ifugao Terraces Commission. Yet, even this feature is exposed to threats, and it was listed in World Heritage in Danger in 2001 and has continuously been addressed by the provincial government of Ifugao. ${ }^{64}$

In addition to the degradation of the Rice Terraces, the population of the Ifugao people working in their farms faces reductions directly due to its youth leaving the traditional way of the Ifugao in pursuit of better opportunities in the cities. ${ }^{65}$ With the younger generation endeavoring to support their family's needs, they have opted to study in universities in the cities and the lowlands, ultimately influencing their decision to leave behind the ways of their people and stay in the metro. ${ }^{66}$ This migration affects the further degradation of the Ifugao traditions due to the gap that it presents in between generations. One of the salient traits of the Ifugao culture is their extensive knowledge of genealogies, wherein their men and

59 Interviewed youth belonging to the Tuwali tribe in Banaue.

60 Malingan, Jamie Joie. "Gotad Ad Ifugao fosters development anchored on Culture and Tourism" (2018) Philippine Information Agency. online: <http://pia.gov.ph/news/articles/1009325>

61 Interviewed a Pastor from the lowlands who attended primary school in Ifugao

62 Interviewed an Ayangan tribe member serving as an employee in the Community Livelihood Center in Lamut

63 Malingan, Jamie Joie. "Gotad Ad Ifugao fosters development anchored on Culture and Tourism" (2018) Philippine Information Agency. online: <http://pia.gov.ph/news/articles/1009325>

64 United Nations Educational, Scientific, and Cultural Organization (UNESCO) "Rice Terraces of the Philippine Cordilleras" (n.d.) online 〈http://whc.unesco.org/en/list/722>

65 Malingan, Jamie Joie. "Gotad Ad Ifugao fosters development anchored on Culture and Tourism" (2018) Philippine Information Agency. online: <http://pia.gov.ph/news/articles/1009325>

66 Interviewed youth belonging to the Tuwali tribe in Banaue. 
women can recite the long list of names of their ancestors and family members. ${ }^{67}$ Comparing the Ifugao people who were born in the $50 \mathrm{~s}$ and the younger generation born in the $90 \mathrm{~s}$, the latter lacks the ability to recall their family members and distant relatives from the tribe. ${ }^{68}$

While education, exposure to the city lives, and economic opportunities are the major factors of the degradation of the Ifugao heritage, younger generations have changed their traditions and often are not aware of what their ancestors practiced due to the promulgation of Christianity. ${ }^{69}$ According to history, most of the Ifugao rites are based on paganism, such as their beliefs in deities and evil spirits and how they affect the health, lives, and fortune of the Ifugao. ${ }^{70}$ Nowadays, most of the Ifugao are Christian. However, some of them, especially the older generations, are still practicing some of the old rituals like "buni" or "funi" which refers to a withcraft ritual ${ }^{71}$ that involves sacrificing pigs and chickens to their deities in order to heal the sick, to curse a person, to exact vengeance, or to counteract "funi" inflicted against them. Some Ifugao practice "funi" to honor their ancestors or give thanks to the Christian Lord. ${ }^{72}$ Present generations refer to the rites of sacrificing animals for different occasions by the generic term, "buni. It is written in historical and anthropological accounts but can also be derived from one of the deities Buni' ad Lagud. Unknown to most of the present generations, Ifugao rites that involve butchering of animals differ in names depending on the intentions of the butcher. ${ }^{74}$ However, younger generations view this kind of ritual as impractical, because the high cost involved in order to have pigs and chicken served. ${ }^{75}$ Another ritual that is viewed negatively by the present generation is called the "bogwa," or the death ritual, which involves the cleansing of the bones, wrapping them in blankets, and keeping them in their homes. ${ }^{76}$ While most of their rites are forgotten, the Ifugao still give importance to the good traditions that they have such as "baddang;" wherein people from the community help one another during harvest and the "imbango," or the engagement, wherein

67 Medina, Carlos “CICM Missionaries and Indigenous Filipinos” (2000) St. Louis University. Cordillera Research and Development Foundation Inc. Baguio City, Philippines at 14

68 Interviewed youth belonging to the Ayangan tribe in Lamut.

69 Interviewed youth belonging to the Tuwali and Ayangan tribes in Banaue and Lamut.

70 Medina, Carlos "CICM Missionaries and Indigenous Filipinos" (2000) St. Louis University. Cordillera Research and Development Foundation Inc. Baguio City, Philippines at 16

71 Goda, Toh "Cordillera: Diversity in Culture Change" (2001). New Day Publishers. Quezon City at 86-129

72 Interviewed a Pastor of the who have visited different Ifugao communities

73 Goda, Toh "Cordillera: Diversity in Culture Change” (2001). New Day Publishers. Quezon City at 86-129

74 Medina, Carlos “CICM Missionaries and Indigenous Filipinos” (2000) St. Louis University. Cordillera Research and Development Foundation Inc. Baguio City, Philippines at 24

75 Interviewed youth belonging to the Tuwali and Ayangan tribes in Banaue and Lamut.

76 Dulawan, Manuel. “The Ifugao" (2006). National Commission on Culture and the Arts, Philippines. at 20 
a man who has plans of marrying a woman will give a pig as a gift to the family and will serve it as a symbol of his true intention to marry the woman. ${ }^{77}$ This exhibits a figment of how the Ifugao practice self-determination but to a lesser extent due to the influences of modern society. ${ }^{78}$

\section{INCLUSIVE DEVELOPMENT IN IFUGAO}

Tourism has become one of the Ifugao's primary sources of living. Modern establishments, such as hotels and lodging houses, are now scattered in the Ifugao area. The diminishing interest in the agricultural prowess of the area is becoming a problem. Even in farming, the use of newer machineries and farming methods have allowed the Ifugao to set aside their traditional ways and focus on attaining a status at par with those living in the lowlands and the cities. ${ }^{79}$ To discourage the flight of the younger generations from the traditions of the Ifugao, the Provincial government increased their support towards the Ifugao by sustaining their economic viability and tourism activities. ${ }^{80}$ Support mechanisms from social services have also reached the Ifugao. In terms of finance, those belonging in the lower socio-economic classes are given access to government programs and projects in accordance to their rights stated in the IPRA. The Department of Social Work and Development (DSWD) also implements the Conditional Cash Transfer (CCT) program, locally known as the Pantawid Pamilya Program (4Ps) to combat poverty through social assistance for the people of Ifugao. These initiatives come in the form of cash assistance, social development, and human capital investments. ${ }^{8182}$ Access to health services, despite being in a state of lax, is still present. In the Banaue area, the Good News Hospital is the single hospital catering for the entire community. For the locals, this hospital is known in the satirical expression: "Nu naka ospital ka Good News!" (You need hospitalization? That's Good News!) ${ }^{83}$ Despite the humor, the residents mentioned that the hospital lacks equipment and is not fairly accessible, especially for residents in the low-lying Barangay of Poitan. To get to the hospital, it requires travelling via a trek

77 Interviewed members of the Ayangan and Tuwali tribes from Banaue, Lamut and Lagawe areas.

78 Solang, Benedict “On Defining Regional Autonomy for the Cordillera” (2011). Cordillera Peoples Alliance. Philippines. at 1

79 Interviewed members of the Ayangan tribe from Banaue.

80 Malingan, Jamie Joie. "Gotad Ad Ifugao fosters development anchored on Culture and Tourism" (2018) Philippine Information Agency. online: 〈http://pia.gov.ph/news/articles/1009325>

81 Reyes, Celia M., Tabuga, Aubrey D. "Conditional Cash Transfer Program in the Philippines: Is it reaching the extremely poor?” (2012). Philippine Institute for Development Studies. 5th Floor, NEDA sa Makati Building, 106 Amorsolo Street, Legaspi Village, Makati City, Philippines. online: 〈https://dirp4.pids.gov.ph/ris/dps/pidsdps1242.pdf> at 2-3

82 Interviewed members of the AyanganI and Tuwali tribe from Banaue, Lamut and Lagawe areas.

83 Ibid 
for 1 hour by foot, using steep foot paths which are only 2 feet in width, located right beside a ravine with no railings. Pharmacies are rampant in the area, and in the interview the respondents mentioned that they have access of healthcare by means of the $4 \mathrm{Ps}$, but it is the lack of the healthcare centers that remains a problem. ${ }^{84}$

Upon observation, the area of the Ifugao have numerous elementary schools and day care centers within 3 to 6 kilometers of each other. Tertiary education is also available at the Ifugao State University in Lamut and Lagawe. Many Ifugao youths are also attending the University of Nueva Viscaya, a province right beside Ifugao. $^{85}$

Agriculture remains part of the primary sources of income for the people of Ifugao, and, throughout the years, other sources such as wood crafting and tourism became part of their economy. However, over the years the Ifugao Rice Terraces have been damaged, eroded, and abandoned, with 500 hectares of the land needing rehabilitation. ${ }^{86}$ Having been introduced to other income-generating means, the Ifugao are also subjected to price hikes in materials and resources. Their products are sold in various stores, but they have also constructed a Provincial Livelihood Center in Lamut that sells the handicrafts and woven items to tourists. This establishment is also managed by members from the Ayangan tribe as part of their cooperative operations.

Religious institutions have also actively influenced the Ifugao. Alternative belief systems geared towards Christianity have encouraged the members of the Ayangan and Tuwali to abandon some of their old beliefs and adopt the Christian way of life. An emphasis is given in the reduction and total removal of "buni," or their ritual of witchcraft, which is deemed to be dually problematic due to its high costs (pigs and livestock are slaughtered in order to feed the entire tribe/community, which will sometimes continue for days) and paganist leanings, as well as "bogwa" (removal of the dead relatives from the graves and placing them inside the house). The organizations, however, also encourage traditions that foster good relations, such as the "baddang," and the "imbango." 88 The impacts of religion are not limited to the reduction of certain traditions and practices. In the case of the Ifugao, the interplay of cultural and religious influences allows the notion of the Ifugao being "uncivilized" to dissipate.

The efforts to help and include IPs in the Phillipines have fostered support from various organizations. The government programs which seek to help and equalize IPs' capabilities and status have already permeated the structures of IP

84 Interviewed members of the AyanganI and Tuwali tribe from Banaue

85 Interviewed AyanganI and Tuwali youth from Banaue and Lamut areas.

86 Rocamora, Joyce Ann L. "DOT to Rehabilitate Banaue Rice Terraces" (2018). Philippine TV News. online: 〈https://www.ptvnews.ph/dot-rehabilitate-banaue-rice-terraces/>

87 Interviewed an Ayangan woodcraftsman from Banaue.

88 Interviewed a pastor and members of the AyanganI and Tuwali tribe from Banaue, Lamut and Lagawe areas. 
communities, as evidenced by the presence of establishments and businesses, particularly hotels, restaurants, pharmacies, variety stores, etc. Pertinent programs that are targeting the poorer IPs such as the Conditional Cash Transfer Program (CCT) have also been delivered. However, some of these programs invoke difficulties in terms of being culturally adequate. The CCT fails to address geographical remoteness, cultural and language needs, and the lack of health and educational infrastructures that offer culturally appropriate services in IP communities. The Department of Health, on the other hand, issued a "No HomeBirthing Policy" that penalizes traditional birthing practices and women who give birth at home. With the lack of basic social services and accessibility to health centers, IPs are subjected to additional burdens. Promoting the cultures of IPs is supported through the Schools of Living Traditions (SLTs) of the National Commission on Culture and the Arts, yet it is open to misrepresentation as it is not under the control of IPs themselves. In terms of education, factors such as remoteness, poverty, costs, and discrimination affect most IPs. In land rights, the government issues land titles for their ancestral lands but encounters problems due to slow registrations with other government agencies. ${ }^{89}$

\section{CONCLUSION}

The idea of cultural preservation, anchored in the need to conserve and protect the culture of a specific social group and to safeguard their identity and status, is greatly beneficial in a multicultural society such as the Philippines. The archipelagic structure of the country is reflected by the society residing in it. The Philippine nation is one that is made diverse by unique differences and various cultures that exist within the country. The mandates of inclusion or the removal of the barriers that divide the society seem to counteract the mandates of cultural preservation that seek to preserve the identity of a specific cultural group. In an effort to bolster the connectedness of every individual through an equitable access to rights and privileges, as well as acceptance, the seemingly competing ideas and their effects are clearly not competing but overlapping.

In the era of rapid urbanization and modernization, the Ifugao, having a different way of life, culture, beliefs, and identity, is affected positively and negatively. The adoption of an inclusive development approach directly and indirectly affects the people of Ifugao. Previous studies suggest that, aside from influencing the youth of the Ifugao to abandon the traditional ways of their people, education and the facets of modernization such as technology, better paying jobs, and the alleviation from poverty sparked the interest and enthusiasm

89 Tebtebba "Situation of Indigenous Peoples in the Philippines: Submission to the 59th Session of CESCR" (2016) online:< http://tebtebba.org/index.php/content/383-situation-of-indigenouspeoples-in-thephilippines-submission-to-the-59th-session-of-cescr> 
of Ifugao youth. Rituals and other traditions are at peril of being lost ${ }^{90}$ taking the precious Ifugao identity along with it. The findings of this research clearly show how the Ifugao culture is gradually being reduced in value with the youth showing disinterest in propagating their traditions reflected by the choice to move to the lowlands and cities, and the efforts of government agencies to reignite it. Even the main feature of the Ifugao, the Banaue Rice terraces, is in danger of damage and degradation. $^{91}$

However, limiting the participation of the Ifugao in the various components of modern society counteracts the provisions given to them by local and international laws and mandates. The overlap begins when the inequalities and exclusions that are addressed, through UNDRIP and IPRA, find it difficult to complement with inclusion. The articles contained in UNDRIP ambiguously express the difference in valuation of "self-determination" and "cultural preservation." The right to pursue a life which a person deems that he or she is entitled to cannot be removed from him or her. However, the responsibility to protect a culture, to which that person belongs to, must be upheld, otherwise the identity of that culture is lost. If a person chooses to adhere more to the principle of self-determination than cultural preservation, should a legal body enact punitive action? In Article 1 of UNDRIP, IPs are entitled to the right to full enjoyment of all fundamental freedoms. ${ }^{92}$ Shouldn't it also entail the freedom to be free from influences that may negatively affect their culture? In the case of the Ifugao, the influences of modern society greatly affect how their youth thinks ${ }^{93}$ which leads to the reduction of the pride that they have in their cultural identity. ${ }^{94}$

This is a dilemma that must be immediately addressed. These ideals must be reconciled and the implementation clarified. Truly, indigenous people are unwittingly becoming forced to adapt to the ways of the majority. It is an injustice for the ethnic minorities to undergo this struggle in our strife to create an inclusive society and build social synchronization. Care, therefore, must be taken in enforcing ideals. Despite a positive intent, its underlying effects might be a

90 Martin, Victor. "Ifugaos' Unique Ritual for the Dead Vanishing" (2017) The Philippine Star. online: <https://www.philstar.com/headlines/2017/11/01/1754835/ifugaos-unique-ritual-deadvanishing>

91 Rocamora, Joyce Ann L. "DOT to Rehabilitate Banaue Rice Terraces" (2018). Philippine TV News. online: 〈https://www.ptvnews.ph/dot-rehabilitate-banaue-rice-terraces/>

92 United Nations "Declaration of the Rights of Indigenous Peoples" (2008). online: <http://www.un.org/esa/socdev/unpfii/documents/DRIPS_en.pdf>

93 Malingan, Jamie Joie. "Gotad Ad Ifugao fosters development anchored on Culture and Tourism" (2018) Philippine Information Agency. online: <http://pia.gov.ph/news/articles/1009325>

94 Dulawan, Manuel. "Ifugao: A sociocultural and Political History" (n.d.) National Commision for Culture and the Arts. Manila, Philippines 
negative one. The need to practice cultural relativism is integral and therefore should be enforced. ${ }^{95}$

\section{RECOMMENDATIONS}

The effort to create a truly global community must include the process of consulting the ethnic minorities and indigenous people, and the effort must be constantly revised so as to streamline their inclusion. This ensures that these communities are represented, their rights are observed, and that all possibilities are explored. We must also consider revising the approaches that are employed in pursuing an inclusive society, because, as it is now, it suggests a one-sided mentality. The current approaches are, directly or indirectly, forcing the indigenous people to transform themselves to absorb different ways in order to fit into the majority. A truly inclusive society should address all differences and come up with solutions that can level and address these differences, equally and equitably, in a manner that is culturally sensitive and accommodating.

The intentions of the mainstream society should be reflected upon. Helping IPs by bringing them the benefits that the mainstream society should not in any way corrupt the community's ideals, traditions and cultural identities. Similarly, the views of IPs being inferior or impractical should be diminished. The stance should be firm: protect and uphold the traditions of IPs for all are one people, and they are no less of a person. A truly inclusive approach will carefully adapt to the diverse needs of its intended recipients.

Given the statements above, the following are therefore recommended:

Practice inclusion under the framework of cultural relativism to ensure that each step in the implementation of inclusive programs is taken with careful consideration for the sensitive but pertinent topics of indigenous culture and traditions. Inclusion should, therefore, accommodate culture through awareness and immersion programs which should be taught in schools. For understanding to occur, it is recommended to subscribe to an adequate philosophical view. Emphatic understanding can be fostered through philosophical views such as:

"Culture is bound by the people who subscribe to it, by the land that hosts and the traditions that it harnesses and passes on; therefore, as citizens of a nation, all is bound by the culture the country that they reside in, however different from each other we may be. Hence, we should forego of the divisive views that we harbor."

95 Thomas-Hoffman, Elizabeth A. "Cultural Preservation and Protection" (n.d.) online: <http://www.mesacc.edu/ bricl07041/un/hs/culture.pdf> at 4 


\section{For the Philippine Government}

For a developing country like the Philippines, it is crucial to garner the support of every citizen in the pursuit of sustainable development. The Phillipine's multicultural society should therefore place an equally important emphasis on IPs in the efforts toward the country's development. In order to do so, the Indigenous People's Rights Act (IPRA) should be revised and added upon. Considering its current scope, the act should be broadened to accommodate actions that will boost the identity of IPs and raise it on equal terms with the mainstream society. Provisions that tackle issues such as the protection of indigenous people's knowledge, systems and practices (IKSPs), the protection from exploitation brought by armed conflicts, discrimination, prejudice, and lack of opportunities for growth in IP areas together with penalties and punitive actions towards offenders must be created through consultation and dialogue with IP communities.

The Ifugao are further marginalized by poverty and social exclusion. Diminish their need to resort to the Conditional Cash Transfer Program (4Ps) by building the capabilities of the Ifugao and focusing on traditional means of living such as agriculture and woodworking by deputizing specific sections of the government to help IPs to not simply become productive members of society but also respected. Upgrade the Provincial Livelihood Center into a stronger organization, acting as both supplier of the products of the Ifugao but also as an advocate seeking to preserve the culture of the area and supports their economic needs. The country should strengthen the agriculture sector to enrich the deteriorating interest of the Ifugao youth towards agriculture and agriculture-based jobs. A strong agriculture sector can garner enough traction to propagate farmers which will enable agriculture-based societies such as the Ifugao to maintain their traditions. Encourage the Ifugao youth to study agriculture and related fields, as well as cultural protection, promotion, and conservation in order to rectify the effect of external influences on them. These should be tackled by respective agencies through a revised framework and plan of action, deputizing them to implement programs and take punitive actions towards offenders and violators. The Philippine Government should enforce this plan through legislations and ordinances and see to its completion.

Apart from capacity building, the mainstream society can also help by employing systems where IPs are represented in sectors of society (i.e. a specific percentage of a company's workforce should be composed of IPs and be allowed to maintain and practice their culture in the context of being a company employee) to reduce the need to classify a specific social group as ethnic, as a minority or as a majority, with geographical, cultural, and other differences rendered moot. In summary, aim for sustainable development using both inclusion and cultural preservation as a framework, ensuring that the overlaps are 
removed and that all barriers, particularly disproportionality in rights reception and privileges and quality of services, are reduced if not utterly diminished.

\section{For Education}

Promoting an equitable form of education involving a systematic identification and needs assessment is more important than focusing on majorities and minorities in addressing the growing disparity. Establish pride in indigenous culture especially in those who do not belong to a specific tribe or IP group through an overhaul of existing policies and ordinances. A Cultural Enrichment program that fosters the acceptance of a culture through a constant valuation and promotion, utterance, and showcasing can help alleviate the "inferior" status of the Ifugao culture. Emphatic understanding is the key in removing prejudices and barriers. Aside from the festivities, programs that boost the pride and understanding of each IP culture should be included in the national curriculum. That being said, the implementation of the Mother-Tongue Based, Multilingual Education (MTB-MLE) should be continued.

Teachers should act as the primary enforcing agents in cultural preservation. As the front liners in the education of the youth, teachers should revalue the appreciation of IP cultures and traditions through their lessons and activities. Implement and observe a "Cultural Month" where students all over the nation are regaled with the various cultures and practices of Phillipine indigenous people, to eliminate the atmosphere of ambiguity and familiarize the youth with the various cultures and ethno-linguistic groups in the country. This may include celebrations, discussions, dialogues, or immersions in IP communities to foster inclusion in the context of preserving cultural identity. And, lastly, improve the conditions of the schools, universities, and colleges in Ifugao, which must include scholarships and other benefits to indigenous students to reduce the need of IPs to migrate to the lowlands and cities just to attain primary to tertiary education. Finally, endorse and implement the creation of a culturally appropriate structure, curriculum and programs.

\section{BIBLIOGRAPHY}

Amores, Analyn, Enkiwe-Abayao, Leah, Martin, Marlon, Tolentino, Delfin “Ifugao: People of the Earth"(2017). ArtPostAsia \& Aboitiz Group of Companies. Philippines

Alicias, Maria Dolores "The Socially Excluded Groups in the Philippines: A Context Analysis for the Voice Program" (2017) Hivos, Oxfam Novib, Ministry of the Foreign Affairs of the Netherlands. 
Ellisiah U.Jocson

Asian Development Bank, "Indigenous Peoples/Ethnic Minorities and Poverty Reduction" (2002) Pasig City, Philippines

Axelrod, Robert "The dissemination of culture: A model with local convergence and global polarization" (1997) The Journal of Conflict Resolution 41(2) 203226. online: <http://users.softlab.ntua.gr/ brensham/CourseSoc/Axelrod1997.pdf>

Best, Jonathan. "A Positive and respectful look at Traditional Ifugao Culture" (Book Review of Ifugao: People of the Earth) (2018). Business World. online: <http://bworldonline.com/positive-respectful-look-traditional-ifugao-culture/>

Birukou, Aliaksandr, Blanzieri,Enrico, Giorgini, Paolo, Giunchiglia, Fausto " $A$ Formal Definition of Culture" (n.d). DISI, University of Trento, via Sommarive $\quad 14, \quad \operatorname{Povo}(\mathrm{TN}), \quad$ Italy $38100 \quad$ online: $<$ https://pdfs.semanticscholar.org/6b6e/052a0c179581ef48b0aa6728b2dea4432c 53.pdf $>$

Booth, Tony and Ainscow, Mel "Index to Inclusion: Developing Learning and Participation in Schools” (2002) Center for Studies in Inclusive Education.

Daley, Jason "Indigenous Peoples Manage One Quarter of the Globe, which is Good News for Conservation” (2018). online: <https://www.smithsonianmag.com/smart-news/indigenous-people-manage-onequarter-globe-which-is-good-news-conservation-180969689/>

Dulawan, Manuel. "The Ifugao" (2006). National Commission on Culture and the Arts, Philippines.

Dulawan, Manuel. "Ifugao: A sociocultural and Political History" (n.d.) National Commision for Culture and the Arts. Manila, Philippines

Ethnic Groups of the Philippines "Ifugao Amganad" (2011). online: $<$ http://www.ethnicgroupsphilippines.com/people/ethnic-groups-in-thephilippines/ifugao-amganad/>

Foundation for the Philippine Environment "Where are Indigenous Peoples Distributed in the Philippines?” (n.d). online: <https://fpe.ph/research/print_mpdf/26>

Goda, Toh "Cordillera: Diversity in Culture Change” (2001). New Day Publishers. Quezon City at 86-129

Goda, Toh. "Urbanization and Formation of Ethnicity in Southeast Asia" (2009) New Day Publishers. Quezon City, Philippines 
Inclusion and Cultural Preservation for the Ifugao People

Ifugao Cultural Heritage Office (ICHO) "2014 State of Conservation Report: Rice Terraces of the Philippine Cordilleras. (2014) Ifugao Cultural Heritage Office \& Philippine National Commision for UNESCO

International Labour Organization "Interregional Programme to Support SelfReliance of Indigenous and Tribal Communities through Cooperatives and Other Self-help Organizations" (2007). online: <http://www.ilo.org/manila/projects/WCMS_125280/lang-en/index.htm>

Kugelmann, Dieter. "The Protection of Minorities and Indigenous Peoples Respecting Cultural Diversity" (2007) Max Planck Yearbook of United Nations Law, Volume 11, 2007. P233-263. Koninklijke. Netherlands

Malingan, Jamie Joie. "Gotad Ad Ifugao fosters development anchored on Culture and Tourism" (2018) Philippine Information Agency. online: $\langle$ http://pia.gov.ph/news/articles/1009325>

Martin, Victor. "Ifugaos' Unique Ritual for the Dead Vanishing" (2017) The Philippine Star. online: $<$ https://www.philstar.com/headlines/2017/11/01/1754835/ifugaos-unique-ritualdead-vanishing>

Medina, Carlos "106 Ifugao Abu'Wab Tales Documented by Frans Lambrecht, CICM from 1932 to 1957” (2001) St. Louis University. Cordillera Research and Development Foundation Inc. Baguio City, Philippines at 1

Medina, Carlos "CICM Missionaries and Indigenous Filipinos" (2000) St. Louis University. Cordillera Research and Development Foundation Inc. Baguio City, Philippines

Metila, Romylyn., Pradilla, Lea Angela., \& Williams, Alan. "Investigating best practice in Mother Tongue-Based Multilingual Education (MTB-MLE) in the Philippines, Phase 2 progress report: Patterns of challenges and strategies in the implementation of mother tongue as medium of instruction in the early years: A nationwide study" (2016). Australian Department of Foreign Affairs and Trade and Philippine Department of Education. Melbourne and Manila: Assessment, Curriculum and Technology Research Centre (ACTRC).

National Commission on Indigenous Peoples "Indigenous Peoples of the Philippines" (n.d) online: 〈http://www.ncipro67.com.ph/indigenous-peoples-ofthe-philippines>>

Philippine Statistics Authority "Ifugao Quickstat" (2018) online: 〈https://psa.gov.ph/content/ifugao-quickstat-june-2018> 
Republic Act No. 8371, “Indigenous Peoples Rights Act" (29 October 1997) <https://www.lawphil.net/statutes/repacts/ra1997/ra_8371_1997.html>

Reyes, Celia M., Tabuga, Aubrey D. "Conditional Cash Transfer Program in the Philippines: Is it reaching the extremely poor?” (2012). Philippine Institute for Development Studies. 5th Floor, NEDA sa Makati Building, 106 Amorsolo Street, Legaspi Village, Makati City, Philippines. online: 〈https://dirp4.pids.gov.ph/ris/dps/pidsdps1242.pdf>

Rocamora, Joyce Ann L. "DOT to Rehabilitate Banaue Rice Terraces" (2018). Philippine TV News. online: 〈https://www.ptvnews.ph/dot-rehabilitate-banauerice-terraces/>

Solang, Benedict "On Defining Regional Autonomy for the Cordillera" (2011). Cordillera Peoples Alliance. Philippines.

Tebtebba "Situation of Indigenous Peoples in the Philippines: Submission to the 59th Session of CESCR" (2016) online:< http://tebtebba.org/index.php/content/383-situation-of-indigenous-peoples-inthephilippines-submission-to-the-59th-session-of-cescr>

Thomas-Hoffman, Elizabeth A. "Cultural Preservation and Protection" (n.d.) online: 〈http://www.mesacc.edu/ -bricl07041/un/hs/culture.pdf>

Tharp, Bruce M. "Defining "Culture" and "Organizational Culture": From Anthropology to the Office" (2009). online: $<$ http://www.thercfgroup.com/files/resources/Defining-Culture-andOrganizationa-Culture_5.pdf>

United Nations "Declaration of the Rights of Indigenous Peoples" (2008). online: 〈http://www.un.org/esa/socdev/unpfii/documents/DRIPS_en.pdf>

United Nations Development Program "Indigenous Peoples of the Philippines" (2013) Makati City $1226 \quad$ Philippines. online: $\measuredangle$ http://www.ph.undp.org/content/philippines/en/home/ibrary/democrat ic governance/FastFacts-IPs.html>

United Nations Development Program "Human Development Report 2016: Human Development for Everyone” (2016) 1 UN Plaza, New York, NY 10017 USA

United Nations Educational, Scientific, and Cultural Organization (UNESCO) "Rice Terraces of the Philippine Cordilleras" (n.d.) online $\langle$ http://whc.unesco.org/en/ist/722> 
United Nations Educational, Scientific and Cultural Organization (UNESCO) "Thematic Paper on Education and Indigenous Peoples: Priorities for Inclusive Education" (2014) Bangkok, Thailand. online: $<$ http://www.un.org/en/ga/president/68/pdf/wcip/IASG\%20Thematic\%20Paper \%20Education\%20-\%20rev1.pdf>

United Nations Educational, Scientific and Cultural Organization (UNESCO) "The Salamanca Statement and Framework for Action on Special Needs Education" (1994) Paris, France. online: < http://unesdoc.unesco.org/images/0009/000984/098427eo.pdf>

United Nations "Conventions on the Rights of the Child" (1989) UNICEF UK 30a Great Sutton Street London. online: 〈https://downloads.unicef.org.uk/wpcontent/uploads/2010/05/UNCRC_united_nations_convention_on_the_rights of the child.pdf? ga $=2.216050582 .1629100116 .1531192672$ $\underline{1628603561.1531192672>}$

United States Department of State "2005-2006 Annual Report on the U.S. Ambassadors Fund for Cultural Preservation" Bureau of Educational and Cultural Affairs, United States Department of State (2006). online: $<$ https://eca.state.gov/files/bureau/2005-6afcpannual.pdf>

Williams, Raymond. "Culture is Ordinary" (1958). Convictions. online: $\langle$ http://www.cs.cmu.edu/ cfrieze/courses/Culture_definitions.pdf>

Wolfsenberger, Wolf P., Nirjie, Bengt, Olshansky, Simon, Perske, Robert, Roos, Philip. "The Principle of Normalization in Human Services.Books: Wofsenberger Collection I" (1972) National Institute on Mental Retardation online: $\langle\underline{\text { http://digitalcommons.unmc.edu/wolf_books/1 }>}$

“Defining Culture and Identities"(n.d). online:

$\langle$ http://www.sagepub.com/sites/default/files/upmbinaries/45974_Chapter_1.pdf> 
Ellisiah U. Jocson is an advocate of the educational needs of institutionalized children and people with disabilities. He obtained his Bachelor's degree in education major in special education from Far Eastern University and is currently pursuing his Master's Degree in Special Education from the University of the Philippines. A special education teacher and a behavior therapist by profession, he finds time to volunteer to organizations that cater to special children such as Virlanie Foundation Inc., Pagkakaisa Volunteers Inc., and Tahan Tahanan Halfway Home. At present, he serves as the managing director of OneLife Foundation Inc., a non-profit organization seeking to establish communities for people with disabilities. 